\title{
The Myth of Murray in The Emperor's Children
}

\author{
Shalece Garff ${ }^{1}$ a \\ ${ }^{1}$ English, Dixie State University \\ Keywords: relationships, reality, messud, claire, murray, perceptions, truth, myth, children, emperor's \\ https://doi.org/10.36898/001c.12498
}

Curiosity: Interdisciplinary Journal of Research and Innovation

Vol. 1, 2020

\begin{abstract}
In Claire Messud's The Emperor's Children, the themes of perception versus reality for Murray Thwaite are particularly central to the story. These themes are analyzed through views of Marina Thwaite, Bootie, Roanne, and Murray himself by using the theoretical lenses of Guy Debord, Friedrich Nietzsche, Simone de Beauvoir, and Ferdinand de Saussure. The ideas of signs and signification, as well as the idea of truth and myths, play a large role in the way that perception acts as a theme in the story. Even in the most intimate relationships involve the deception that Murray represents as a character. Though Murray acts as a deceiver, he is not operating as one due to his own will, but due to the circumstances in which society has placed him in. Thus, the operations of deception are not capable of being influenced by the individual; they are set up and standardized by society as a whole.
\end{abstract}

What people perceive a person to be is not necessarily what they are. A person might be perceived one way when the reality is that they are not that way at all. Many times, perceptions are falsified views of what people want to see rather than what they actually see. This theme of perception versus reality is evident in Claire Messud's The Emperor's Children through Murray Thwaite's character. While using theories from Friedrich Nietzsche, Ferdinand de Saussure, and Simone de Beauvoir as well as other scholarly sources, I will examine the theme through the eyes of Marina Thwaite, Bootie, Roanne, and Murray himself.

To understand how the characters view Murray, I will first describe the theories and what they entail. In Friedrich Nietzsche's "On Truth and Lying in a Non-Moral Sense" (2018) he describes his theory of lying and truth: what it is, and why people do it. Lying happens when "[People] are deeply immersed in illusions and dream-images; their eyes merely glide across the surface of things and see 'forms"' (p. 753). The 'form' of a thing is simply the idea of it instead of the actual thing. Nietzsche believes that people choose not to see what is truth and accept the lies. The reasoning he (2018) gives for people accepting lies is, "Truth, too, is only desired by human beings in a similarly limited sense. They desire the pleasant, life-preserving consequences of truth...they are actually

\footnotetext{
a Shalece S. Garff is a senior at Dixie State University and majoring in English-Literary Studies. Since she began studying at Dixie State University, she has received the Edna Gregerson English Scholarship and earned the English Literary Studies Student of the Semester Award for fall 2019. Shalece has also served in the officer core of Dixie State's Sigma Tau Delta as the Convention Liaison as well as being invited to present at Sigma Tau Delta's Annual Convention. Her most recent work has been working as an associate editor for Roger Corman's New World Pictures (1970-1983): An Oral History. Shalece plans to go on to pursue her MA in English Literature after graduating. She can be reached at shalecegarff@gmail.com.
} 
hostile towards truths which may be harmful and destructive" (Nietzsche, 2018, p. 754). Human beings only want to accept the truths that are beneficial for them and their lives; they reject the truths that can damage the perceptions that they hold so dear.

Like Nietzsche, Ferdinand de Saussure also has a theory that is pertinent to the idea of perception versus reality in Murray's character. In his Course in General Linguistics, Saussure (2018) details his theory about signs and signification. Saussure writes, "[The sign] is the social side of speech, outside the individual who can never create nor modify it by himself; it exists only by virtue of a sort of contract signed by the members of a community" (p. 824). The signified and the signifier make up the sign. An example would be the object, marker, which is the signified, and the word 'marker' when it is said, is the signifier. According to the abovementioned quote: people cannot decide what a sign means as individuals, it is society that agrees on what a sign means, together as a whole.

Simone de Beauvoir's The Second Sex, like Saussure and Nietzsche, details a theory that is also relevant in describing the theme of perception versus reality in Murray's character. Though Beauvoir's writing focuses mainly on feminism and the myth of woman, it also brought to light a very important concept. Beauvoir (2018) writes, "Yes, most myths have their roots in man's spontaneous attitude to his own existence” (p. 1219). A person's very sense of self depends on the myths that they choose to believe. It is possible to say that a person might not even know who they are without the lies that they accept into their lives as truth.

Roanne Levine, a student who listened to one of Murray Thwaite's lectures, expresses the first concrete view of Murray in The Emperor's Children. After one considers Roanne's blushing and flirtatious giggling, it is clear that she idealizes Murray, and, because of that, her perception of him and his character is clouded. Murray flirts back, somewhat subtlety with Roanne by asking her out for drinks, and afterward, her phone number (Messud, 2006, p. 37). In Roanne's article about Murray, she describes him as versatile, erudite, and controversial (Messud, 2006, p. 53); she also describes his appearance, calling him a "tall, handsome man" (Messud, 2006, p. 53). Roanne uses her article as a way to perpetuate the myth of Murray, the untouchable and perfect intellectual. She sees Murray as the form of an intellectual, writing influential journalistic pieces and traveling to despondent parts of the world, instead of how he actually is. In this way, Roanne's views of Murray are Nietzschean. Nietzsche (2018) writes, "Just as it is certain that no leaf is ever exactly the same as any other leaf, it is equally certain that the concept 'leaf' is formed by dropping these individual differences arbitrarily, by forgetting those features which differentiate one thing from another, so that the concept then gives rise to the notion that something other than leaves exists in nature, something which would be 'leaf,' a primal form” (p. 755). Roanne is applying her grand ideas of intellectualism and the form of an intellectual to Murray and choosing not to see who he really is. 
Guy Debord's The Society of the Spectacle is also applicable to Roanne's perception of Murray. Debord's theory is similar to that of Nietzsche; however, it is still different. Debord (2014) writes, "Everything that has directly lived has receded into a representation" (p. 1). This is similar to that of Nietzsche's idea of form, however, while Nietzsche says that there is just an idea, a form of an object, Debord says that there was once a real image that has since "receded." Murray would be considered a spectacle in Debord's theory, a representation of what was once considered an intellectual. Debord (2014) summarizes Roanne's perception and relationship of Murray in his writing, "The root of the spectacle is that oldest of all social specializations, the specialization of power" (p. 7). Murray, in his position as a spectacle, holds power over Roanne as an authority figure and a representation of an intellectual.

Like Roanne, Bootie also has an outside perspective of who Murray Thwaite is. Bootie regards his uncle as one who is above all else. In Bootie's mind, his uncle his elevated far more than even his own father. He believes that he and Murray have some sort of inner connection because they are both intellectuals. Messud (2006) writes, "He had to get to New York, for this: to his as yet unalerted teacher and mentor. To Murray Thwaite" (p. 104). Bootie seeks out his uncle because he feels like he is not understood as a scholar himself in his intimate circle at home. Shortly after arriving, Bootie feels a strong connection with Murray, "Murray Thwaite had known exactly what Bootie was trying to do, exactly how meaningful, how vital, even, the undertaking was. He had known exactly" (Messud, 2006, p. 202). Bootie feels like he has found his "truth" and that, while living with his uncle Murray, he has found his place. At this point, Bootie is in a situation that Nietzsche (2018) describes, "But human beings themselves have an unconquerable urge to let themselves be deceived, and they are as if enchanted with happiness when the bard recites epic fairytales as if they were true" (p. 760). According to Nietzsche, Bootie sees only the good in Murray because that's all he wants to see. He sees an idea, a form of what he feels is a desirable condition-a life as an intellectual-and plays into the fantasy of it, disregarding any of the realities that might come with such a life.

However, after discovering Murray's manuscript, Bootie goes from calling Murray "proof that you didn't have to give in to deceit" (Messud, 2006, p. 205) to "an imposing façade, to be sure; but a hollow monument" (Messud, 2006, p. 239). Bootie's perception of Murray changes after he discovers that his uncle is, in fact, not the mentor that he expected him to be. Murray is an example of the spectacle in Debord's theory, and Bootie is a spectator. Debord (2014) writes, "The spectator does not feel at home anywhere, because the spectacle is everywhere" (p. 11). Bootie can never understand or become a part of the world in which the spectacle rules because it goes against everything he believes in. Debord (2014) explains, "The spectacle presents itself simultaneously as society itself, as a part of society, and as a means of unification" (p. 1). Murray represents a falsified society, a piece of the falsified society, and brings people together by believing in the lie of who he is. It is said best by Simone de 
Beauvoir (2018), "Mystery is never more than a mirage; it vanishes as soon as one tries to approach it" (p. 1219). This holds true to Bootie and his investigation of Murray's mysterious character. The second Bootie tried to get to know who Murray truly was, his real character had disappeared. The idealistic perception that young Bootie had of his uncle disappeared when he got to close.

Marina Thwaite, Murray's daughter, has been blissfully deceived by her father even though she was closer to him than Bootie ever was. She sees her father as an impossibly high standard. Messud (2006) wrote, “...but you don't have any idea what it's like to be Murray Thwaite's daughter"” (p. 52). The way Marina sees herself is dependent on how she sees her father; thus, her sense of self depends on the myth of Murray. Ryan Stolier and Jonathan Freeman (2016) wrote, "Perception has long been presumed to play an integral role in social cognition and subsequent behavior. Our interferences, judgments, and actions toward a person are, of course, driven by how we perceive that person" (p. 352). Because Marina perceives her father to be a great and upstanding man, she is intimidated by his presence and does whatever he asks of her. She does not question him or his decision-making because he is the great Murray. Messud (2006) wrote, "Marina was sitting cross-legged on the carpet in shorts and a tank top, her back firmly against the wall, collating and labeling the articles she had downloaded and printed out for her father" (p. 125). She goes on to say that Murray wanted the articles quickly and that she was trying her best to get them to him. It is not until Murray reads her book that Marina realizes who her father truly is. In response to Murray's remarks, Marina says, "Except it's not clear to me, Daddy, that you have respect for anyone at all. I just don't think that you do"' (Messud, 2006, p. 323). Marina has now come to see the conclusion that her father is a man who has respect for the preservation of himself and his craft and little concern regarding others. This change, from Marina's idolization of her father to the downright disgust and disappointment with his character, is what happens when one's perception of a person must come to face reality.

It is possible that Marina, and the rest of the people that Murray interacts with, are seen as an "Other" in his eyes. Beauvoir's essay focuses on the inferior nature between men and women, and though Murray's views are not based on gender, Beauvoir's viewpoint still applies. Beauvoir (2018) writes, "In the eyes of men...the 'real woman' is one who accepts herself as Other" (p. 1220). In regards to this example involving Marina and Murray Thwaite, the quote could be changed to: "In the eyes of [Murray] the [good Marina] is one who accepts herself as Other." Murray sees himself as the superior being in comparison to the rest of his peers. This feeling of superiority might not be a façade on Murray's part, though. Guy Debord (2014) wrote, "The specialization of images of the world [or spectacle] has culminated in a world of autonomized images where even the deceivers are deceived" (p. 1). Murray is simply a victim of the society that he lives in, unaware of the deception that he is distributing to all who know him. 
How Murray perceives himself is tied to how he expects others to treat him. Messud (2006) wrote, "Nobody touched his papers, nobody moved his piles, nobody entered the inner sanctum unbidden: as he had explained more than once... and he relied upon his household to behave accordingly" (p. 68). Murray is the man, the head, nay, the ruler of his household. It is his household, and because the myth of male dominance is over them, his family agrees because the myth is central to their existence (de Beauvoir, 2018, p. 1219). This ties back to Marina helping her father with the articles. Murray must consider himself to be above printing and organizing the articles himself, so he designates the task to his daughter, who he regards as inferior to himself.

Not only does Murray believe his daughter is inferior to himself, but he also believes that his nephew, Bootie, is below him. When Murray reads the article that Bootie wrote about him, he says to his nephew, "Do you know what you are? You're a little shit, a nothing, you have the intellect of a moth. You're a speck of filth from Watertown, New York, which is itself a speck of filth. You're a nothing'" (Messud, 2006, p. 337). Murray believes that Bootie has the ability to damage his reputation, and the fear causes him to lash out. Patrick Heck and Joachim Kreuger (2016) explain, "This research begins with the assumption that if peers or observers regard a self-enhancer [Murray] positively, they contribute to that person's social well-being. Conversely, if they regard a selfenhancer negatively, they put the person's social well-being at risk" (p. 330). Murray knows that if the article were to get out, and people were to believe it, it could ruin the life that he has made for himself. The article could be a step in the signifier and the signified changing. Saussure (2018) wrote, "The bond between the signifier and the signified is arbitrary" (p. 828). There is no direct connection to Murray as a signifier and to what he signifies, which, in this case, is a successful intellectual. Because there is no direct connection between signifier and signified, it can change, but not because of the desire of one individual. Saussure (2018) wrote, "The individual does not have power to change a sign in any way once it has become established in the linguistic community" (p. 828). Murray does not choose what he signifies or even if he is a signifier. The community in which he is a part of decides, and he, as an individual, cannot make decisions for the group. Because of this, if Bootie's article were to change the minds of masses on who Murray really is, the sign of an intellectual would be capable of changing.

The deception that occurs in The Emperor's Children is due to Murray's false presentation of himself. According to theories discussed by Beauvoir, Debord, Saussure, and Nietzsche, this is not entirely or even partly a problem in which readers can place blame on Murray's shoulders. Murray, as a human being, operates within the society that has been built around him, all the while influencing the people who look to him as a social structure or sign. The specific perceptions of Roanne, Bootie, and Marina show how perception and reality are pitted against each other, even when somewhat intimate relationships are involved with the deceiver. It is Murray himself, though, that brings full circle the concept of what is perceivable from the outside as well 
as from the inside. His views bring into question the idea that he is likely not aware of the system in which he is operating as a signifier, a spectacle, a selfenhancer, a myth, and a deceiver. Nietzsche said it best: "What do human beings really know about themselves?" (2018, p. 753). 


\section{References}

de Beauvoir, S. (2018). The Second Sex. In The Norton Anthology of Theory and Criticism (3rd ed., pp. 1214-1221). Norton \& Company Limited.

de Saussure, F. (2018). Course in General Linguistics. In Norton Anthology of Theory and Criticism (3rd ed., pp. 824-840). Norton \& Company Limited.

Debord, G., \& Knabb, K. (2014). The Society of the Spectacle. Bureau of Public Secrets.

Heck, P. R., \& Krueger, J. I. (2016). Social Perception of Self-Enhancement Bias and Error. Social Psychology, 47(6), 327-339. https://doi.org/10.1027/1864-9335/a000287

Messud, C. (2006). The Emperor's Children. Vintage Books.

Nietzsche, F. (2018). On Truth and Lying in a Non-Moral Sense. In The Norton Anthology of Theory and Criticism (3rd ed., pp. 752-762). Norton \& Company Limited.

Stolier, R. M., \& Freeman, J. B. (n.d.). Functional and Temporal Considerations for Top-Down Influences in Social Perception. Psychological Inquiry, 27(6), 352-357. 